\title{
Simulation of the processes of heat- and the mass transfer in the rooms of public building with the natural ventilation
}

\author{
Maria Prorokova ${ }^{1, *}$, Vyacheslav Bukhmirov ${ }^{1}$ \\ ${ }^{1}$ State Educational Institution of Higher Professional Education Ivanovo State Power University \\ named after V.I. Lenin, 1153003 Ivanovo, Russia
}

\begin{abstract}
In the article the mathematical model of the processes of heat exchange and mass exchange in the room of building with the natural ventilation is shown. The verification of mathematical model is performed via the comparison of the results of calculation in ANSYS Fluent with the data of experiment. Experiment was conducted in the room of educational institution. In the experiment were measured the temperature of air, air speed and moisture content in air. A low relative error in the calculation with the use of a mathematical model makes its use for predicting the parameters of microclimate after the introduction of the energy-saving measures possible
\end{abstract}

\section{The mathematical model of the processes of heat exchange and mass exchange in the room}

The prediction of the parameters of microclimate in the rooms of habitable, public and office buildings is urgent task. Solution of this problem will make it possible to estimate influence on the microclimate of the rooms of factors, connected with the energy-saving measures [1].

For the solution of this problem in Ivanovo State Power University was used the method of mathematical simulation. The thermal, humid and air regime of room was described by such parameters as the temperature of air $\left(\mathrm{T}_{\mathrm{B}},{ }^{0} \mathrm{C}\right)$, air speed $(\mathrm{w}, \mathrm{m} / \mathrm{s})$, moisture content $(\mathrm{d}$, $\left.\mathrm{kg} / \mathrm{kg}_{\text {d.a. }}\right)$ and the concentration of carbon dioxide $\left(\mathrm{CO}_{2}, \mathrm{ppm}\right)$. For calculating these parameters the system of differential equations, which contains the equation of the conservation of energy, pulse and quantity of substance, and also the integral-differential equation of the transfer of the radiant energy, was solved [2-4].

The standard k- $\varepsilon$ model of turbulence was used for calculating the turbulent properties of air in the room [5]. The realization of the mathematical model of the processes of heatmass transfer is executed in ANSYS Fluent [6]. The solution of the equations of the transfer in ANSYS Fluent is based on the method of final volumes.

\footnotetext{
* Corresponding author: prorokova mv@list.ru
} 


\section{The verification of the mathematical model}

The verification of the mathematical model of microclimate in the room was executed by the comparison of the results of calculation in ANSYS Fluent with the data of experiment. In the experiment in the room were measured the temperature, air speed and moisture content in air. Measurements are taken on height $0.1,0.6$ and $1.7 \mathrm{~m}$ from the floor (for the rooms, in which the people the large part of the time sit) [7].

During the first stage calculation in ANSYS Fluent is built the geometric model of experimental room (figure 1) and with the aid of the grid editor Meshing to the calculated region it is superimposed Cartesian multilevel grid (method CutCell). The automatic generation of adapted grid made it possible to obtain grid from 1488278 the elements and 1817190 the units with the quality of the elements average by the volume of calculated region 0.98 . The exterior view of calculated grid is represented in the figure 2 .

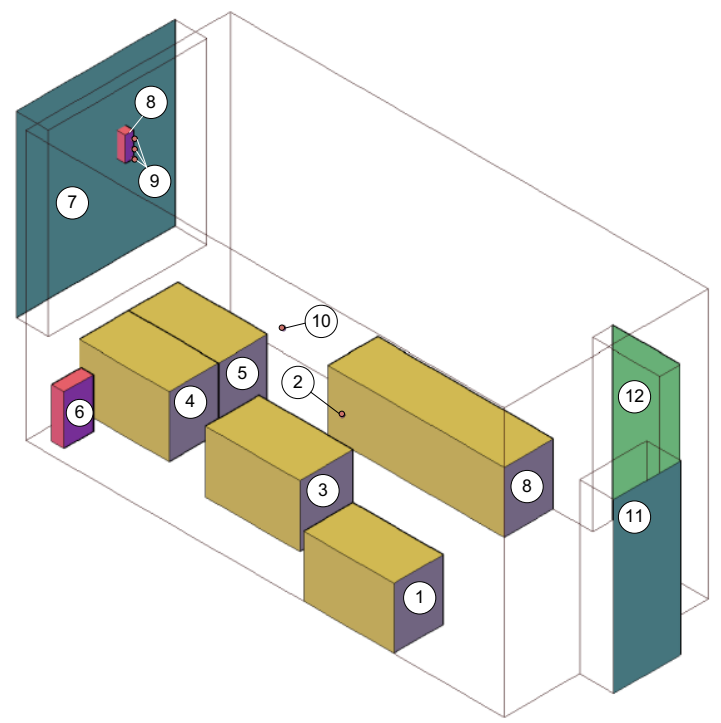

Fig. 1. The geometric model of the experimental room: 1, 3, 4, 5, 8-table; 2, 10 -the sensors, which measure the parameters of air; 6 - the source of the heat (oil cooler); 7 - window; 8 - the source of the heat (heat-fan); 9 - sensor for measuring the parameters of surrounding air; 11, 12 - the door.

In the calculation it is accepted:

- air in the room is of four component mixture of nitrogen $\left(\mathrm{N}_{2}\right)$, of oxygen $\left(\mathrm{O}_{2}\right)$, of carbon dioxide $\left(\mathrm{CO}_{2}\right)$ and of water vapour $\left(\mathrm{H}_{2} \mathrm{O}\right)$;

- air is subordinated by ideal gas law;

- air in the room is diathermy;

- air it enters evenly only on the perimeter of window.

For describing the boundary conditions of task the results of the experiment were used: the mean temperature of the surfaces of room, the temperature of air, the moisture content in air, air velocity and the composition of surrounding air, the temperature of the surface of man, composition and the temperature of air, which inhales and breathes out men, power of the source of heat (oil cooler). 

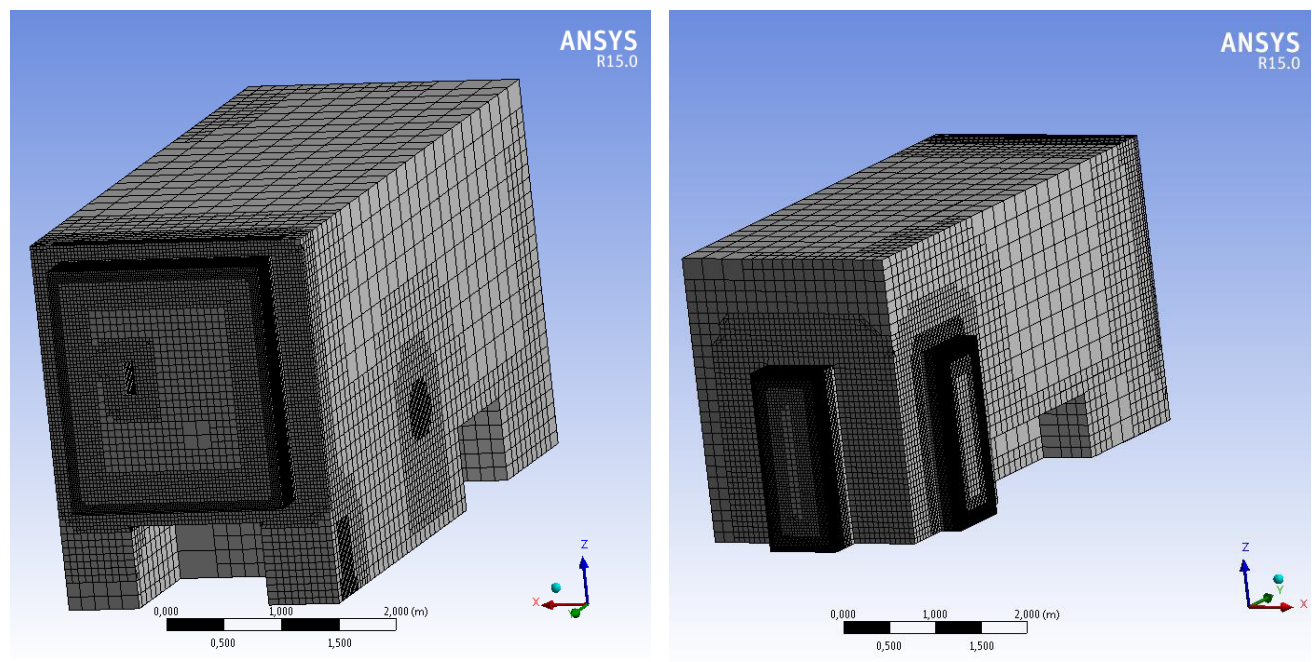

Fig. 1. Computational grid.

With the mathematical simulation of microclimate in the experimental room the influence of air composition on the basic parameters of microclimate was investigated. Calculations are executed for two air compositions:

- air in the room and tributary, and breathed out by man consists of the mixture of two gases: of nitrogen $\left(\mathrm{N}_{2}\right)$ and oxygen $\left(\mathrm{O}_{2}\right)$;

- air in the room is the four-component mixture, which consists of nitrogen $\left(\mathrm{N}_{2}\right)$, of oxygen $\left(\mathrm{O}_{2}\right)$, of carbon dioxide $\left(\mathrm{CO}_{2}\right)$ and of water vapour $\left(\mathrm{H}_{2} \mathrm{O}\right)$.

Problem is solved for steady state of heat exchange and mass exchange with the application of the method Pseudo Transient.

The results of calculation and experiment are given in the figures 3, 4 and 5 .

In the tables 1 and 2 is given an relative error in calculated temperature and moisture content in air in ANSYS Fluent (in comparison with the experiment).
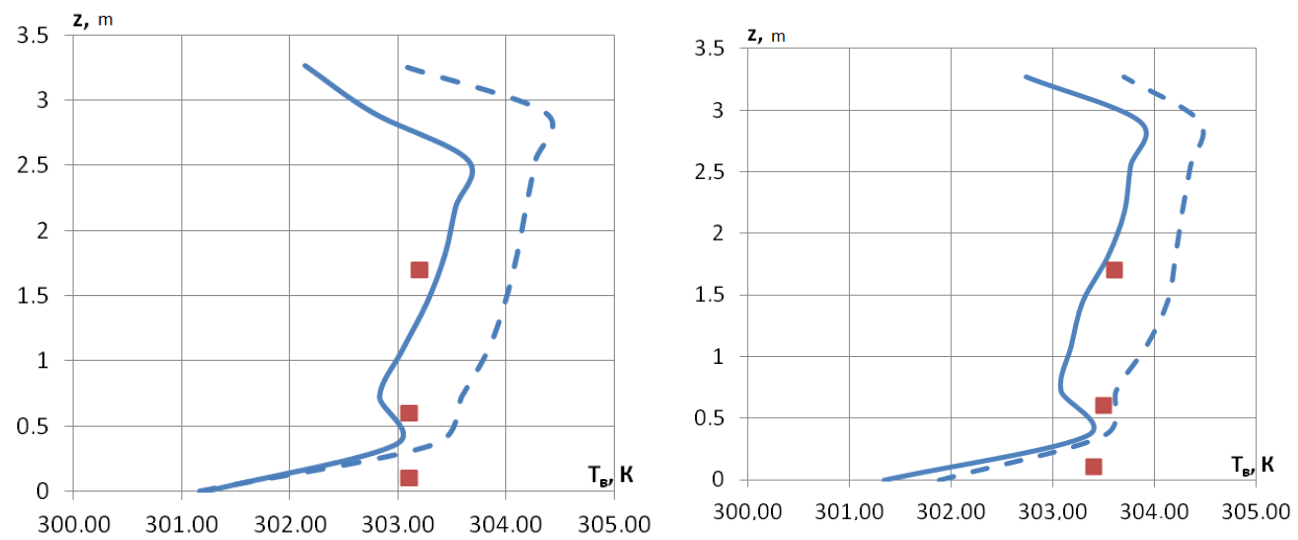

Fig. 3. The temperature of air in the room: continuous line - air consists of four components $\left(\mathrm{N}_{2}, \mathrm{O}_{2}\right.$, $\mathrm{CO}_{2}$ and $\left.\mathrm{H}_{2} \mathrm{O}\right)$; dashed line - air consists of two components $\left(\mathrm{N}_{2}\right.$ and $\left.\mathrm{O}_{2}\right)$; point - the experiment. 

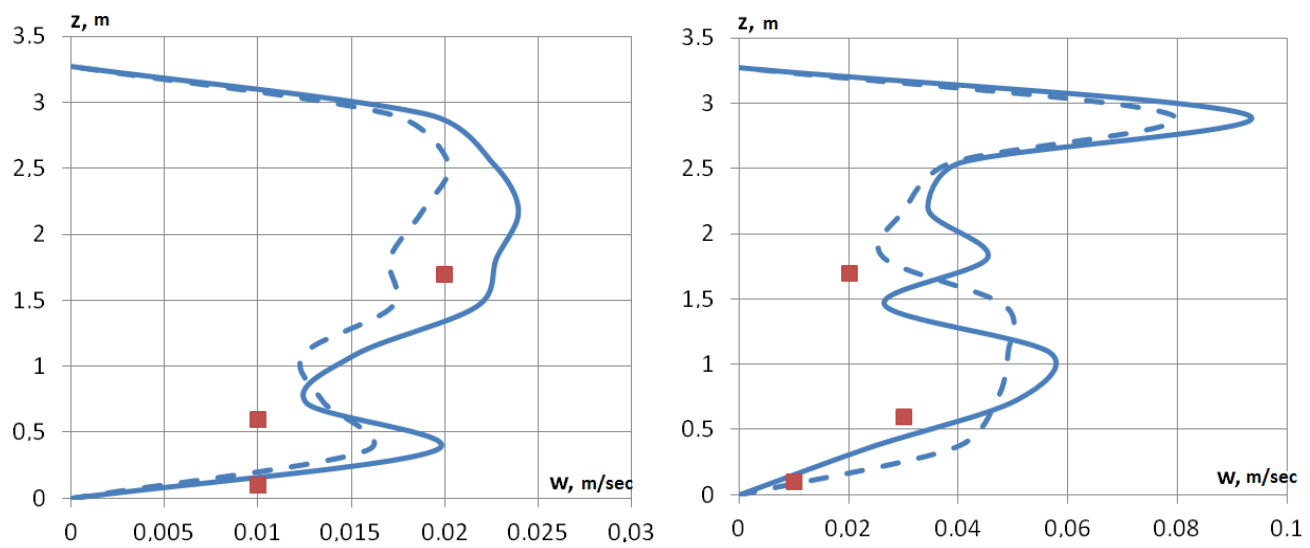

Fig. 4. The velocity of air in the room: continuous line - air consists of four components $\left(\mathrm{N}_{2}, \mathrm{O}_{2}, \mathrm{CO}_{2}\right.$ and $\left.\mathrm{H}_{2} \mathrm{O}\right)$; dashed line - air consists of two components $\left(\mathrm{N}_{2}\right.$ and $\left.\mathrm{O}_{2}\right)$; point - the experiment.

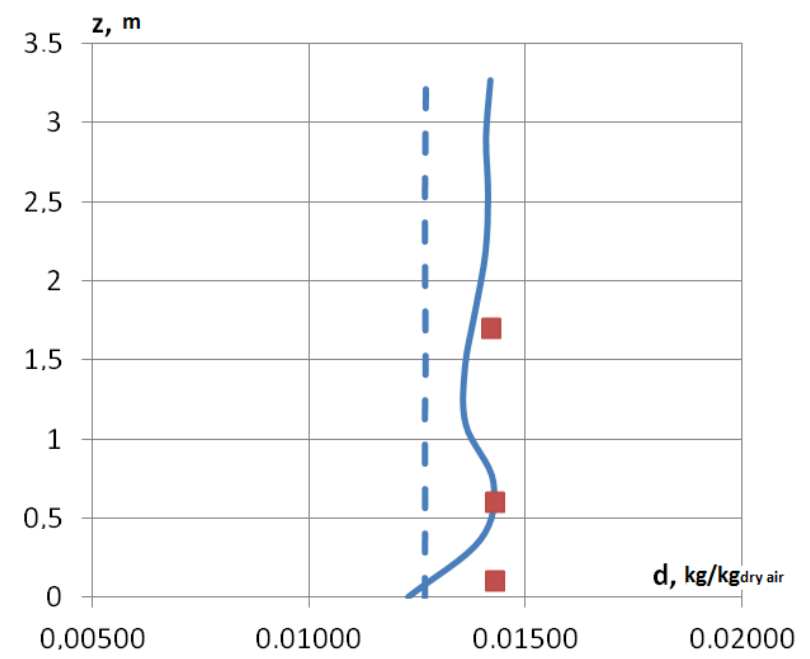

Fig. 5. Moisture content of the air in the room: continuous line - air consists of four components $\left(\mathrm{N}_{2}\right.$, $\mathrm{O}_{2}, \mathrm{CO}_{2}$ and $\left.\mathrm{H}_{2} \mathrm{O}\right)$; dashed line - air consists of two components $\left(\mathrm{N}_{2}\right.$ and $\left.\mathrm{O}_{2}\right)$; point - the experiment.

Table 1. An error in the calculated temperature of air in ANSYS Fluent.

\begin{tabular}{|c|c|c|c|c|c|c|}
\hline \multirow{2}{*}{$\begin{array}{l}\text { № the } \\
\text { point }\end{array}$} & \multirow{2}{*}{$\begin{array}{l}\text { Height } \\
\text { above } \\
\text { floor } \\
\text { level, } \mathrm{m}\end{array}$} & \multirow{2}{*}{$\begin{array}{c}\mathrm{T}_{\mathrm{B}}, \mathrm{K} \\
\text { (experiment) }\end{array}$} & \multicolumn{2}{|c|}{$\begin{array}{l}\text { Air consists of two } \\
\text { components }\end{array}$} & \multicolumn{2}{|c|}{$\begin{array}{l}\text { Air consists of four } \\
\text { components }\end{array}$} \\
\hline & & & $\begin{array}{c}\mathrm{T}_{\mathrm{B}}, \mathrm{K} \\
\text { (calculation) }\end{array}$ & $\begin{array}{l}\text { Relative } \\
\text { error, \% }\end{array}$ & $\begin{array}{c}\mathrm{T}_{\mathrm{B}}, \mathrm{K} \\
\text { (calculation) }\end{array}$ & $\begin{array}{l}\text { Relative } \\
\text { error, \% }\end{array}$ \\
\hline \multirow{3}{*}{1} & 0.1 & 303.1 & 301.94 & 3.85 & 302.18 & 3.06 \\
\hline & 0.6 & 303.1 & 303.67 & 1.89 & 303.05 & 0.17 \\
\hline & 1.7 & 303.2 & 303.95 & 2.48 & 303.37 & 0.56 \\
\hline \multirow{3}{*}{2} & 0.1 & 303.4 & 302.05 & 4.44 & 302.50 & 2.96 \\
\hline & 0.6 & 303.5 & 303.80 & 0.98 & 303.35 & 0.49 \\
\hline & 1.7 & 303.6 & 304.47 & 2.84 & 303.33 & 0.88 \\
\hline
\end{tabular}


Table 2. An error in the calculated moisture content of the air in ANSYS Fluent.

\begin{tabular}{|c|c|c|c|c|c|c|}
\hline \multirow{2}{*}{$\begin{array}{c}\text { № the } \\
\text { point }\end{array}$} & $\begin{array}{c}\text { Height } \\
\text { above } \\
\text { floor } \\
\text { level, } \mathrm{m}\end{array}$ & $\begin{array}{c}\mathrm{d}, \mathrm{kg} / \mathrm{kg}_{\text {d.a. }} \\
\text { (experiment) }\end{array}$ & \multicolumn{2}{|c|}{$\begin{array}{c}\text { Air consists of two } \\
\text { components }\end{array}$} & \multicolumn{2}{c|}{$\begin{array}{c}\text { Air consists of four } \\
\text { components }\end{array}$} \\
\cline { 4 - 7 } & & $\begin{array}{c}\mathrm{d}, \mathrm{kg} / \mathrm{kg}_{\text {d.a. }} \\
\text { (calculation) }\end{array}$ & $\begin{array}{c}\text { Relative } \\
\text { error, \% }\end{array}$ & $\begin{array}{c}\mathrm{d}, \mathrm{kg} / \mathrm{kg}_{\text {d.a. }} \\
\text { (calculation) }\end{array}$ & $\begin{array}{c}\text { Relative } \\
\text { error, \% }\end{array}$ \\
\hline \multirow{3}{*}{1} & 0.1 & 0.0143 & 0.0127 & 11.19 & 0.0130 & 9.09 \\
\cline { 2 - 7 } & 0.6 & 0.0143 & 0.0127 & 11.19 & 0.0142 & 0.70 \\
\cline { 2 - 7 } & 1.7 & 0.0142 & 0.0127 & 10.56 & 0.0151 & 6.34 \\
\hline
\end{tabular}

The analysis of figures 3, 4 and 5 and tables 1 and 2 shows that the calculation of water vapour and carbon dioxide in air increases the accuracy of the mathematical simulation of microclimate. A difference in the calculated and experimental values of the air speed and moisture content is caused by both the error in the numerical calculation and by error in the experimental determination of these parameters.

\section{Conclusion}

Is proposed and realized in ANSYS Fluent the mathematical model of the processes of heat transfer and mass transfer in the room of building, which considers water vapour and carbon dioxide in air. Is proven the authenticity of mathematical model with the aid of the comparison of the results of calculation with the experimental data.

\section{References}

1. V.V. Bukhmirov, M.V. Prorokova, Vestnik IGEU 4 (2015) [in Russian]

2. B. Gebkhart, Y. Dzhaluriya, R. Mekhadzhan, B. Sammakiya, Svobodnokonvektivnye techeniya, teplo- i massoobmen (Mir, Moscow, 1991) [in Russian]

3. Yu.A. Tabunshchikov, M.A. Brodach, AVOK, 2002 [in Russian]

4. A.M. Grimitlin, T.A. Datsyuk, D.M. Denisikhina, AVOK Severo-Zapad, 2013 [in Russian]

5. I.A. Belov, S.A. Isaev, Modelirovanie turbulentnykh techeniy (Balt. gos. tekhn. un-t, 2001) [in Russian]

6. I. Weinhold, J. Parry, The Three Waves of Commercial CFD. URL: www.mentor.com [12.07.2016]

7. GOST 30494-2011 Zdaniya zhilye $i$ obshchestvennye. Parametry mikroklimata $v$ pomeshchenii (2011) 